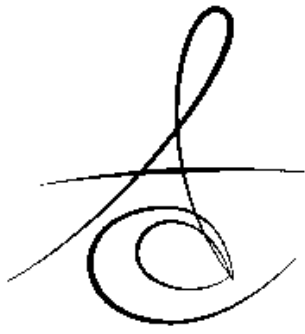

Makale Kodu/Article code: 1861

Makale Gönderilme tarihi: 23.09.2014

Kabul Tarihi: 08.12.2014

\section{SOS1 ASSOCIATED NOONAN SYNDROME PRESENTING WITH SUPERNUMARY TEETH; A CASE REPORT}

\section{SOS1 GENİ İZOLE EDİLEN NOONAN SENDROMLU OLGUDA ARTI DİŞ; BİR OLGU SUNUMU}

\author{
Dr. Gülser KILINÇ* \\ Dt. Müjdet ÇETÍN* \\ Dr. Özge AKSEL ${ }^{* *}$ \\ Doç Dr. Hüseyin ONAY*** \\ Doç Dr. Özlem Giray BOZKAYA ${ }^{* * * *}$
}

\section{ÖZET}

Noonan sendromu (NS) oldukça yaygın görülen otozomal dominant bir hastalıktır. Bu hastalık, konjenital kalp hastalığı, boy kısalığı, göğüs deformasyonu ve farklı yüz özellikleri ile karakterizedir. Noonan sendromunda yaygın gingivit olmasına karşın artı dişler nadir olarak görülmektedir.

Bu vaka raporunda NS'lu 12 yaşında bir erkek hastayı sunulmaktadır. Ağız içi incelemesinde anterior açık kapanış, süpernumere dişler, ön bölge dişetlerinde büyüme, diastema, konik kesici dişler, dar ve yüksek damak yapısı ve belirgin rugalar gözlenmektedir.

Hastada mevcut klinik bulgular doğrultusunda Noonan sendromu düşünülmüş olup periferik kandan yapılan SOS1 geni analizinde 11. ekzonda p.R552K mutasyonu bulunmuştur.

NS'lu hastalarda artı dişlere bağlı dental problemler görülebilmektedir. Bu olguların takip ve tedavileri sırasında çocuk diş hekimleri ile işbirliği gereklidir.

Keywords: Noonan sendromu, artı diş, SOS1, gingivit.

Keywords: Noonan syndrome, supernumerary teeth, SOS1, gingivitis

\section{INTRODUCTION}

Noonan syndrome (NS) was first described by Noonan and Ehmke in $1963 .^{1}$ NS is a common autosomal dominant multiple congenital anomaly syndrome which is characterized by craniofacial abnormalities, congenital cardiac defects and short stature. $^{2,3}$ The prevalence ranges between $1 / 1000$ and $1 / 2500 \cdot{ }^{1,3,4}$ This syndrome can be seen in both of two genders at the same rate. It is also named as "Turner like syndrome" and "male Turner syndrome" based on similar findings with Turner Syndrome. ${ }^{1,5,6}$

The phenotype shows variability due to causative mutations. The most frequent clinical features observed in NS patients are webbed neck,

${ }^{*}$ Dokuz Eylul University Faculty Of Medicine, Pediatric Dental Clinic.

** Dokuz Eylul University Faculty Of Medicine, Department of Medical Genetics.

${ }^{* * *}$ Ege University Faculty Of Medicine, Department of Medical Genetics.

${ }^{* * * *}$ Dokuz Eylul University Faculty of Medicine, Department of Pediatrics, Division of Genetics and Department of Medical Genetics 
Atatürk Üniv. Diş Hek. Fak. Derg.

J Dent Fac Atatürk Uni

Supplement: 12, YIl: 2015, Sayfa : 56-60

chest deforma tions, pulmonic stenosis, short stature and distinctive craniofacial features including hypertelorism,ptosis, downslanting palpebral fissures and low set ears. Inaddition, mild mental retardation, bleeding diathesis, cryptorchidism, refractive errors and skin changes are seen in NS patients. ${ }^{1,3,4}$ Molecular testing can be used for confirming the diagnosis when the clinical findings are not typical for NS. About $50 \%$ of NS patients have mutations in PTPN11 gene which encodes SHP-2, a cytoplasmic protein tyrosine phosphatase that plays a role in cell proliferation. ${ }^{7,8}$ Furthermore, mutations in the SOS1, RAF1, KRAS, MEK2, SHOC2 and NRAS genes whose products have a role in Ras signal pathway should be screened in patients with clinical findings of NS who have not PTPN11 gene mutation. ${ }^{9}$ Missense mutations in SOS1 are present in about $10 \%$ NS patients. SOS1 encodes a guanine exchange factor that catalyzes the release of GDP from inactive Ras. ${ }^{10}$ Lee et al. ${ }^{11}$ reported that multiple giant cell lesions of the mandible and maxilla can be seen in NS patients. In this report, we aimed to present the case of a 12year-old boy who has supernumery teeth and a pathogenetic mutation in the SOS1 gene.

\section{CASE REPORT}

A 12-year-old boy referred to Dokuz Eylul University Children's Dental Clinic for abnormal shape of incisors. On his oral examination, two supernumerary teeth were detected in the anterior region of the maxilla. In addition, distinct and short maxillary frenulum, diastema and open-bite in the anterior, narrow high-arched palate, severe anterior gingival enlargement, two supernumarary teeth and prominent rugae were noted (Figure 1,2,3). Tooth decay in first permanent right and left lower molars were determined. The upper right permanent canine was fractured. Two supernumerary teeth were found in the frontal maxillary in the panoramic radiography of the patient (Figure 4). No other abnormalities or dental anomalies were detected. The patient and his family were informed about the objectives and scope of the treatment. The informed consent has been taken from patient's parents.
KILINÇ, AKSEL, ÇETİN, ONAY, BOZKAYA

\section{Clinical Treatment}

The patient's two existing supernumerary teeth were extracted (Figure 5). First permanent left and right molar teeth in the mandibula were restored with composite filling. The gingival treatment applied and the oral hygiene education was given to the patient. Orthodontic treatment planning was done for the patient.

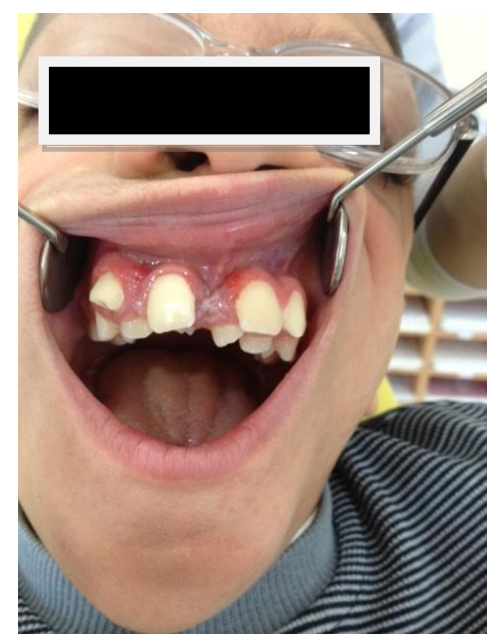

Figure 1. Intraoral view of the patient.

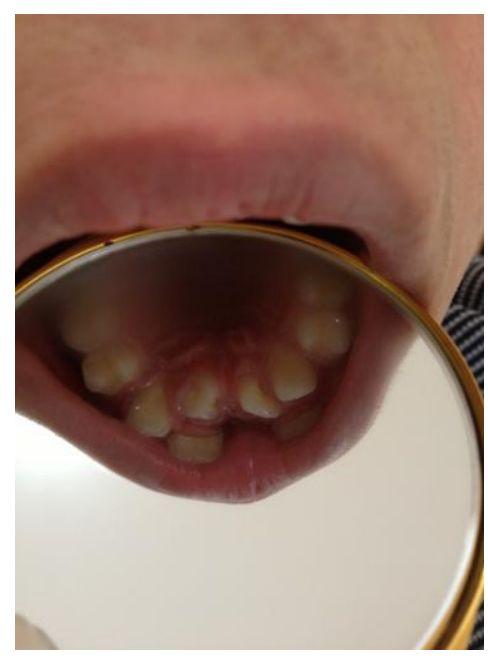

Figure 2. Supernumary teeth of the patient. 
Atatürk Üniv. Diş Hek. Fak. Derg.

J Dent Fac Atatürk Uni

Supplement: 12, YIl: 2015, Sayfa : 56-60
KILINÇ, AKSEL, ÇETİN, ONAY, BOZKAYA

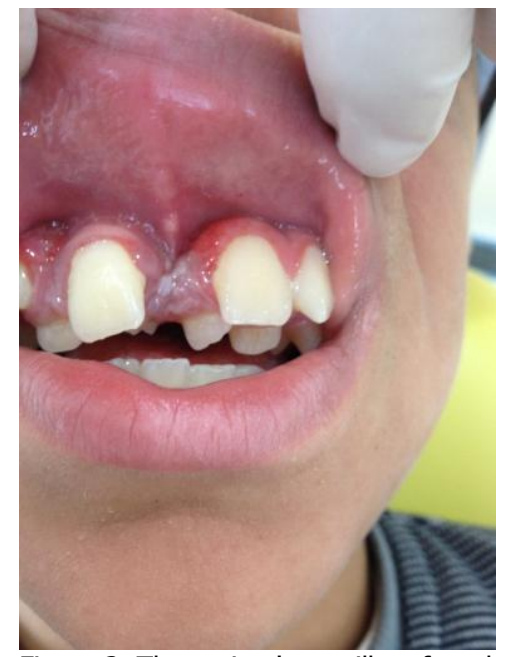

Figure 3. The patient's maxillary frenulum.

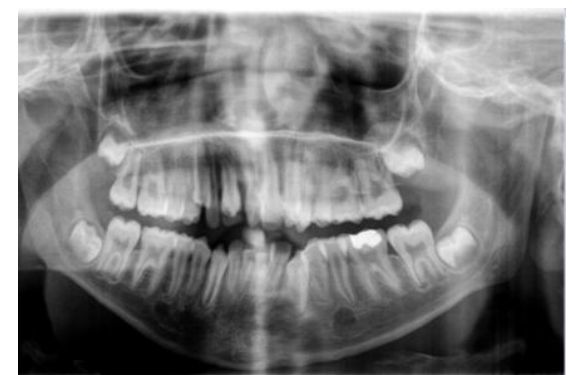

Figure 4. The panoramic radiography of the patient.

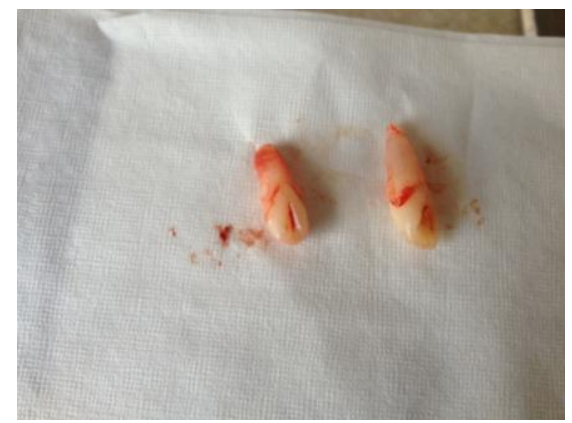

Figure 5. Extracted teeth of the patient.

\section{Genetic Finding}

The patient was referred to pediatric genetics department for short stature, sparse eyebrows, low set ears and hearing loss. On his physical examination, his weight and height were $34 \mathrm{~kg}$ (between the 10th and the 25th percentiles) and $138.5 \mathrm{~cm}$ (between the 10th and the 25th percentiles). He had low set ears, bilateral proptosis, sparse eyebrows, epicanthal folds, hypertelorism, down slanting palpebral fissures, depressed nasal bridge, webbed neck, low posterior hairline, pectus excavatum, cubitus valgus (Figure 6). Also, the left testicle was non-palpable. In the patient's eye examination, myopia was noted. Echocardiography and abdominopelvic ultrasonography revealed normal findings. Skeletal radiographs demonstrated scoliosis in the lower thoracic spine which might be positional. He was consulted with pediatric surgery department for cryptorchidism and an operation was planned. Karyotype analysis from peripheral blood lymphocytes yielded normal result. Based on his clinical findings the diagnosis was considered as Noonan syndrome. Mutation analysis of the BRAF, PTPN11 and SOS1 genes from peripheral blood cells was showed a mutation in SOS1 gene.

\section{DISCUSSION AND CONCLUSION}

Noonan syndrome is characterized by short stature, congenital cardiac defects, chest deformity, webbed neck, craniofacial abnormalities including low set ears, hypertelorism, epicanthal folds, proptosis, depressed nasal bridge, cryptorchidism and learning disability. ${ }^{3}$ Many of these anomalies were present in our patient, such as chest deformities (pectus excavatum), hypertelorism, epicanthal folds, depress sed nasal bridge, bilateral proptosis and left sided cryptorchidism. Although our patient's echocardiography was normal, it's known that two-thirds of NS patients have congenital cardiac defects such as pulmonary valve stenosis, hypertrophic cardiomyopathy, and cardiac septal defects. ${ }^{12}$ Various ocular anomalies like strabismus and refractive errors have been reported in patients with NS. ${ }^{13} \mathrm{~A}$ typical chest deformity (pectus carinatum and/or excavatum) occurs in $70-95 \%$ of all NS patients, just like in our patient. In addition, the other skeletal abnormalities including cubitus valgus, clinobrachydactyly and thoracic scoliosis are reported. ${ }^{13}$ Hepatosplenomegaly is present in approximately $50 \%$ of patients, however our patients physical examination and abdominal ultrasonography has shown these organs to be in normal size. ${ }^{13,14}$ Female patients have normal fertility whereas male fertility is known to be reduced. Male gonadal dysfunction is thought to be a result of primary Sertoli cell dysfunction even though cryptorchidism is seen in approximately $80 \%$ of all male NS patients. ${ }^{15}$ Medical and/or surgical treatment

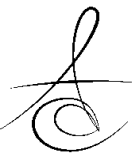


Atatürk Üniv. Diş Hek. Fak. Derg.

J Dent Fac Atatürk Uni

Supplement: 12, Yıl: 2015, Sayfa : 56-60
KILINÇ, AKSEL, ÇETİN, ONAY, BOZKAYA and follow-ups were planned by physicians for myopia, pectus excavatum, cubitus valgus, throcic scoliosis and cryptorchidism found in our patient.

Narrow high-arched palate, dental anomalies, microglossia and prominent rugae are the most common oral findings in NS patients. ${ }^{3,11}$ In addition to these, two supernumerary teeth were found on our patients oral examination. Hereditary is believed to be an important etiological factor in the occurrence of supernumerary teeth. ${ }^{16}$ Although there are many cases of children with NS and dental abnormalities reported, ${ }^{8,11,12,17,18}$ there were only two previous cases with supernumerary teeth reported in the childhood. ${ }^{17,18}$ Mutation analysis of these cases with supernumerary teeth were not mentioned. ${ }^{17,18}$ Asokan et al. ${ }^{8}$ described a case with distinct and short maxillary frenulum and diastema. Our patient has distinct and short maxillary frenulum, diastema and open-bite in the anterior. It is reported that periodontal problems may occur in patients with NS due to a lack of space in the jaw. ${ }^{12,17}$ Gingivitis was noted in present case, therefore oral hygiene education has been given and gum treatment applied to the patient. Orthodontic treatment was planned for the patient for the lack of space in the jaw. Similarly, many studies have been made in orthodontic treatment of patients with NS. ${ }^{8,12}$

Mutation analysis of the SOS1 gene from peripheral blood cells showed that our patient has p.R552K mutation in exon 11 of the SOS1 gene which is the second common gene mutation causing NS. Missense mutations in SOS1 are present in about $10 \%$ of all NS patients. ${ }^{10}$ SOS1 mutation positive NS patients have more frequently pulmonic stenosis, ectodermal changes whereas they have less intellectual disability, atrial septal defect and short stature. Ectodermal changes and facial features that are seen in NS patients with SOS1 mutation resembles cardiocutaneous syndrome. ${ }^{15,18}$ Roberts et al. ${ }^{19}$ described 13 patients with mutations in SOS1; 5 of them had cryptorchidism and 4 of them did not have any cardiac anomaly. Our patient's clinical findings are similar with these SOS1 mutation positive patients.

In conclusion, dental problems like supernumary teeth might be seen in NS patients. It is necessary to collaborate with pediatric dentist during the follow-up and treatments of these cases.

\section{REFERENCES}

1. Noonan JA, Ehmeke DA. Associated noncardiac malformation in children with congenital heart disease. J Pediatr 1963; 63:468-70.

2. Noonan JA. Noonan syndrome. An update and review for the primary pediatrician. Clin Pediatr (Phila) 1994; 33:548-55.

3. Altunoğlu U, Denayer E, Rosti RÖ, Karaman B, Kayserili H. Genotype-Phenotype Correlation in Turkish Noonan Syndrome Population. Turkiye Klinikleri J Pediatr 2009; 18:174-80.

4. Mendez HM, Opitz JM. Noonan syndrome: a review. Am J Med Genet 1985; 21:493-506.

5. Marino B, Digilio MC, Toscano A, Giannotti A, Dallapiccola $B$. Congenital heart diseases in children with Noonan syndrome: An expanded cardiac spectrum with high prevalence of atrioventricular canal. J Pediatr 1999; 135:703-6.

6. Lemire EG. Noonan syndrome or new autosomal dominant condition with coarctation of the aorta, hypertrophic cardiomyopathy, and minor anomalies. Am J Med Genet 2002;113:286-90.

7. Tartaglia M, Mehler EL, Goldberg R, Zampino G, Brunner $H G$, Kremer $H$, et al. Mutations in PTPN11, encoding the protein tyrosine phosphatase SHP-2, cause Noonan syndrome. Nat Genet 2001; 9:465-8.

8. Asokan S, Muthu MS, Prabhu VR. Noonan syndrome: a case report. J Indian Soc Pedod Prev Dent 2007; 25: 144-7.

9. Derbent M, Öncel Y, Gürsu A, Varan B. A Patient with Noonan Syndrome Caused by the SOS1 Gene Mutation: Case Report. T Klinikleri J Pediatr 2012; 21:121-5.

10. Tartaglia M, Gelb BD. Molecular genetics of Noonan syndrome. In: Zenker M., editor. Monographs in Human Genetics Vol. 17. Noonan syndrome and related disorders: A matter of deregulated Ras signaling. 1 ed. Basel; Karger Press: 2009. p. 20-39.

11. Lee SM, Cooper JC. Noonan syndrome with giant cell lesions. J Indian Soc Pedod Prev Dent 2005; 15:140-5.

12. Emral ME, Akcam MO. Noonan syndrome: a case report. J Oral Sience 2009; 51:301-6.

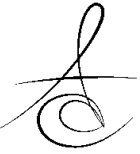


13. Van der Burgt I. Noonan syndrome. Orphanet J Rare Diseas 2007; 2:4.

14. Allanson JE. The Clinical Phenotype of Noonan Syndrome. In: Zenker M., editor. Monographs in Human Genetics Vol. 17. Noonan syndrome and related disorders: A matter of deregulated Ras signaling. 1 ed. Basel; Karger Press: 2009,9-19.

15. Roberts $A E$, Allanson JE, Tartaglia M, Gelb BD. Noonan syndrome. Lancet 2013; 26:333-42.

16. Ezirganlı Ş, Ün E, Kırtay $M$, Özer $K$, Köşger $H H$. Sivas bölgesindeki artı dişlerin yaygınlığının araştırılması. 2011; 21: 189-95.

17. Toureno L, Park JH. Atypical orofacial conditions in Noonan syndrome: A case report. J Clin Pediatr Dent 2011; 36:197-202.

18. Tartaglia M, Gelb BD, Zenker $M$. Noonan syndrome and clinically related disorders. Best Pract Res Clin Endocrinol Metab 2011; 25:16179.

19. Roberts $A E$, Araki $T$, Swanson KD, Montgomery KT, Schiripo TA, Joshi VA, Li L, Yassin Y, Tamburino AM, Neel BG, Kucherlapati RS. Germline gain-of-function mutations in SOS1 cause Noonan syndrome. Nat Genet 2007; 39: 70-4.

\section{Yazışma Adresi}

Dr. Gülser KILINÇ

Dokuz Eylül Üniversitesi

Tıp Fakültesi, Çocuk Diş Kliniği,

İzmir, Türkiye

Tel: 00902324122181

e-mail: gulser.kilinc@deu.edu.tr 